\title{
Effect of Endogamy and Consanguinity on the Development of Labial Venous Malformations in Area of Tlemcen (West Algeria)
}

\author{
Badr-Eddine Sari ${ }^{1,}$, Mourad Aribi ${ }^{*, 2,}$ and Badia Saari ${ }^{3}$
}

\author{
${ }^{I}$ Pathology and Oral Surgery Department, University Medical Center, Tlemcen 13 000, Algeria \\ ${ }^{2}$ Biotoxicology Laboratory, Research National Center, Faculty of Sciences, Sidi-Bel-Abbes Djillali Liabes University, \\ Sidi-Bel-Abbes, 22 000, and Toxicomed Laboratory, Faculty of Medical Sciences, Tlemcen Abou-Bekr Belkaïd \\ University, Tlemcen, 13 000. Algeria \\ ${ }^{3}$ Pathology and Oral Surgery Department, Mustapha Hospital, Algiers 16 000, Algeria
}

\begin{abstract}
Background: Vascular malformation is extremely rare, yet has a profound impact on quality of life, aesthetic and functional disorders. Aim: To show that endogamy and consanguinity may represent risk factors for labial venous malformation (LVM) development. Materials and Methodology: Among the 18093 scrutinized families on a 20 years back period from marriage registers, five families with a child presenting LVM were recruited from two geographic areas, one highly endogamous (Nedroma), the other slightly endogamous (Maghnia). These families were recruited for a retrospective descriptive essay at the Pathology and Oral Surgery Department of Tlemcen University Hospital Center (north-west of Algeria). Results: Four cases of LVM were from the Nedroma region, the fifth one from the Maghnia region. High consanguinity level was registered in patient families from Nedroma. On the other hand, the blood group O frequency was slightly higher compared to that of the blood group non-O. Conclusions: The present study suggests that consanguinity could beget LVM and that endogamy could increase its prevalence. The postulated association between this genetic disease and the OO genotype seems to be not confirmed. Therefore, it would be interesting to seek the SNP markers in this region.
\end{abstract}

\section{INTRODUCTION}

Angioma is a recurring term used to designate some pathological abnormality, whether tumorous or malformative. The only common point between those two is the vascular system, which is affected in both cases (capillaries, veins, arteries, lymphatic vessels) [1]. It has become classical and convenient however to oppose vascular tumors (mostly cellular hemangioma) to vascular malformations [2]. Although rare, those malformations have been classified into four main types: capillaries, venous, lymphatic or otherwise artero-venous [3]. Vascular malformations in turn have been sub-classified as either venous or capillaro-venous, with infiltration that eventually becomes serious [4].

As for every other vascular malformation, venous malformations result from a vascular morphogenesis error [5]. While present at birth, those malformations progress slowly [6] and are generally detected either at adolescence or consequently to some traumatic circumstances. Facial forms may be localized in lips, eyelids or tongue $[7,8]$, and are often responsible for aesthetic and functional disorders. Although what causes those malformations is still unknown, the malformations could be generated from some genetic factors [911]. Indeed, a mutation on chromosome $9 \mathrm{p} 21$ of a gene that

\footnotetext{
*Address correspondence to this author at the Biotoxicology Laboratory, Research National Center, Faculty of Sciences, Sidi-Bel-Abbes Djillali Liabes University, Sidi-Bel-Abbes, 22 000, and Toxicomed Laboratory, Faculty of Medical Sciences, Tlemcen Abou-Bekr Belkaïd University, Tlemcen, 13 000, Algeria; Tel: +213.432.662.23; Fax: +213.432.643.17; Email:m_aribi@mail.univ-tlemcen.dz and m_aribi@yahoo.fr

${ }^{\S}$ Contributed equally to this work.
}

identifies substitution of a sole amino acid and causes ligand-independent activation of an endothelial cell specific receptor tyrosine kinase (TIE-2) domain was found. Moreover, existence of genotype heterogeneity among families with venous - cutaneomucous malformations was prominently displayed [3], leading to the conclusion that other factors and genes are involved. Hence, Brouillard and colleagues [12] recently highlighted a mutation of a - glomuline - gene for inherited cutaneous venous anomalies. This mutation would be involved in the development of glomuvenous malformations, even of multiple glomangiomatose familiar, which are not linked to 9p21, but instead link to a new locus on $1 \mathrm{p} 21$ p22, called VMGLOM (LOD score 12.70 with q 3D 0,00 ), bordered by AFMa205XD5 and D1S2775. However, their non-depressible and very painful characters on palpation, differentiate them to other types of venous malformations [13].

Due to their extremely rare occurrence, facially localized vascular malformations and notably those of venous or capillaro-venous type have so far shown considerable worldwide paucity in data and information, Algeria included. Considering the genetic factors implication in their appearance, the remarkably high level of consanguinity especially in north-west of Algeria $[14,15]$, as well as the endogamy and consanguinity affects descendants (polymalformations, higher frequency association of pathogenic genes, rare and recessive diseases [16-18], we conjectured a potential involvement of endogamy and consanguinity in LVM development. Thus, a retrospective descriptive essay, including 18093 families among which five have a child with a LVM was accomplished at the Pathology and Oral surgery Department of Tlemcen University Hospital Center (north-west of Algeria). It is noteworthy that these families were selected from two separate geographic localities, 
one highly endogamous (Nedroma), the other slightly endogamous however (Maghnia).

\section{MATERIALS AND METHODOLOGY}

\section{Subjects and Patients}

From June 2005 to June 2007, 18093 families were scrutinized on a twenty years back period from marriage registers at the City Halls of Nedroma and Maghnia. The same letter was sent to all families, inviting those with a child presenting a labial malformation, for free consultation at the Pathology and Oral surgery Department of Tlemcen University Hospital Center (north-west of Algeria). Subsequently, five families having a child with LVM (Fig. 1) were retained for the actual study. All parents of the patients are not affected.

Patient recruiting was done on a basis of clinical examination, identifying any labial malformation of blue depressible mass or under-mucous sheath, non-pounding and nonblowing yet increasing of volume when the patient is in an inclined position. The complementary histological examination carried out after chirurgy step showed thick and hyaline vessels with endarteritis and vascular thrombosis pictures, as well as bordered venous lakes with endothelial cells (Fig. 2). Inclusion criteria consisted in geographic locality (Nedroma and Maghnia) and strictly labial localization of the malformation. Exclusion criteria consisted in artero-venous malformations. The study was carried out with Good Clinical Practice Guidelines and the Declaration of Helsinki, and was approved by the Scientific Council of Faculty of Medical Sciences, Tlemcen Abou-Bekr Belkaïd University. A questionnaire was distributed among all participants who in turn provided signed informed consent [19]. The mean age at the disease evolution peak was $12 \pm 1$ (range: 11-13 years).

\section{Consanguinity Analysis and ABo Phenotyping Patients}

Detailed three-generation pedigrees were drawn to analyze the consanguinity coefficient in the five recruted families. An analysis of the ABo group was made to identify the phenotype of all subjects and patients. ABo typing was performed using monoclonal antibodies (anti-A, anti-B and anti $\mathrm{A}+\mathrm{B})$ on whole blood samples collected in acid citrate dextrose (ACD)-contained tubes. Additionally, isogglutinin serum and erythrocyte tests were equally performed in order to unambiguously validate the serological test.

\section{RESULTS}

Four cases of LVM were recruited in Nedroma area and only one case from the Maghnia region. Results correspond to a prevalence of four cases/38000 inhabitants in Nedroma, and 1 case/70000 inhabitants prevalence in Maghnia. Moreover, malformation frequency as far as the studied families is of $8.14 \times 10^{-4}(4 / 4912)$ and of $0.76 \times 10^{-4}$ $(1 / 13181)$ respectively to both regions. Therefore, risk of appearance for such pathology is almost 11 times higher in Nedroma than in Maghnia.

On the other hand, the highest consanguinity level was recorded in patient families of Nedroma region, with a mean consanguinity coefficient of 0.051. That of the Maghnia patient family was estimated to 0.016 . Moreover, it should be stated that all patients from Nedroma were females (Table 1).
Assessment of the frequency of $\mathrm{ABo}$ antigens and heterozygous and homozygous $\mathrm{A}, \mathrm{B}, \mathrm{O}$ alleles in patients with LVM and in their parents is resumed in Table 2.
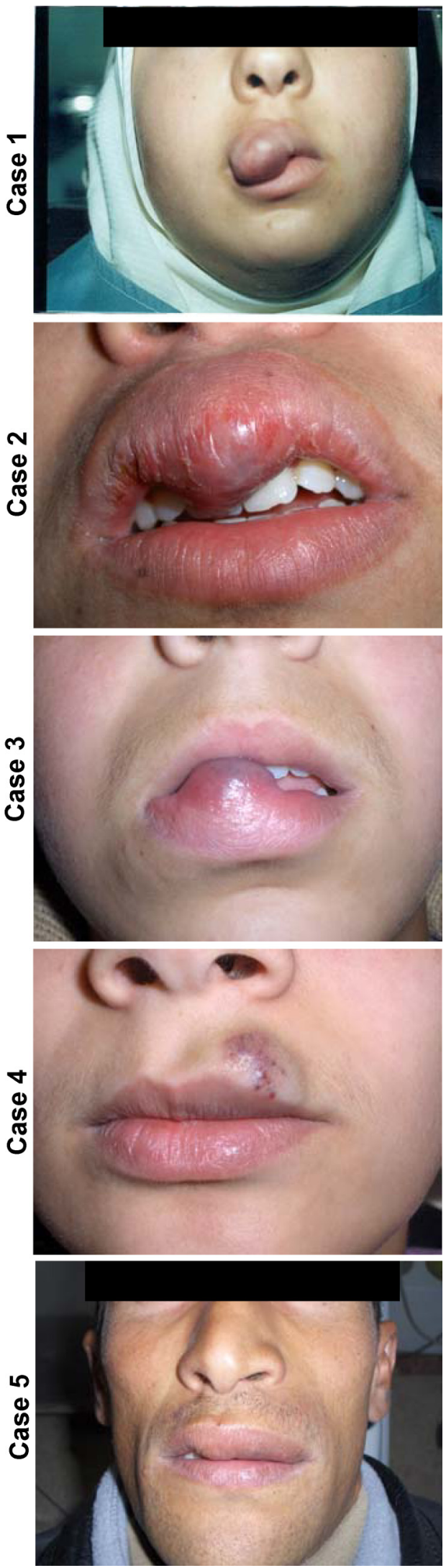

Fig. (1). Patients with labial venous malformations of the current study. 
(A)

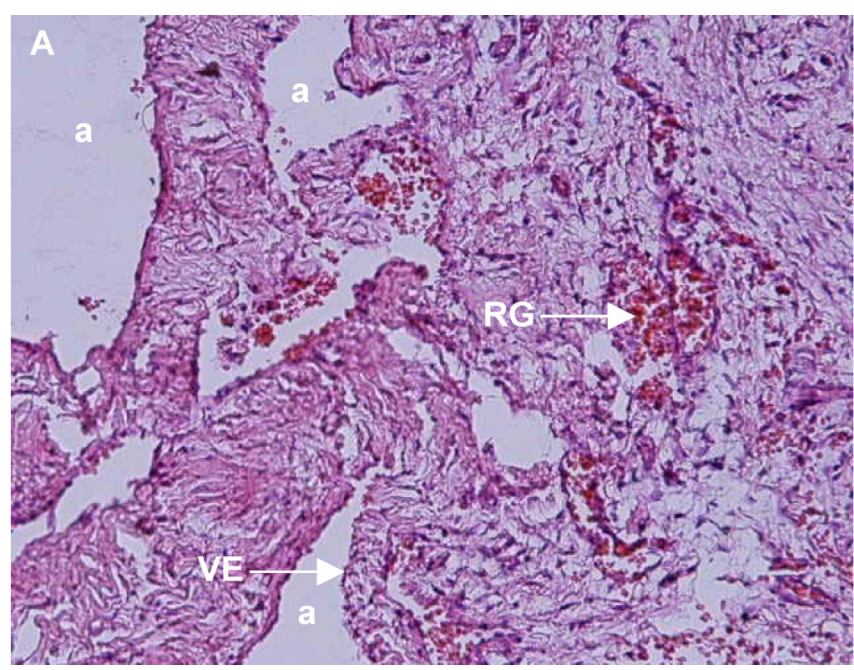

(B)

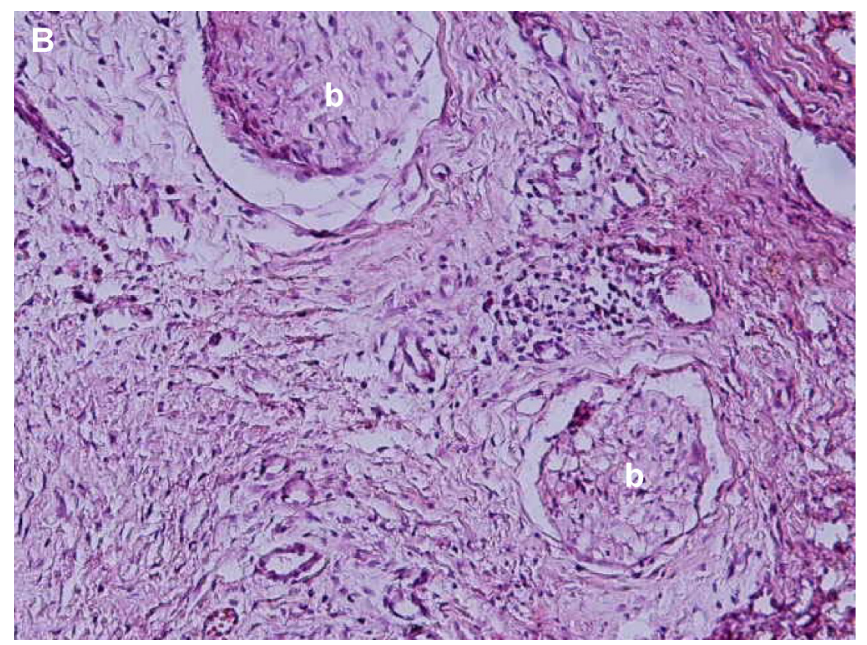

Fig. (2). Histological analysis of venous labial malformation. Postsurgical histological layers were stained with hematoxylin-eosin (H-E). (A) a: vascular cavity; RG: red globules; VE: vascular endothelium. (B) b: vascular thrombosis.

Table 1. Prevalence of Labial Venous Malformation in Nedroma and Maghnia Regions (Tlemcen Area, North-West of Algeria)

\begin{tabular}{|l|c|c|}
\hline \multirow{2}{*}{} & \multicolumn{2}{|c|}{ Region } \\
\cline { 2 - 3 } & Nedroma & Maghnia \\
\hline \hline Number of inhabitants & 38000 & 70000 \\
\hline Number of scrutinized families & 4912 & 13181 \\
\hline Number of children with LVM & 4 & 1 \\
\hline LVM frequency & $8.14 \times 10^{-4}$ & $0.76 \times 10^{-4}$ \\
\hline Consanguinity degree of eligible families & $5.1 \%$ & $1.6 \%$ \\
\hline
\end{tabular}

LVM: labial venous malformation.

Unlike the Maghnia family, the frequency of homozygote alleles of the ABo system is higher than that of heterozygote alleles in the Nedroma area families $(61.15 \%$ vs $38.85 \%)$. It is noteworthy on the other hand a weak increase in the frequency of the $\mathrm{O}$ alleles relatively to non-O alleles, i.e. all subjects: $16(57.1 \%)$ vs 12 (42.9\%); patients with LVM: 3 $(60 \%)$ vs $2(40 \%)$ respectively.

\section{DISCUSSION}

Spouse choice have direct consequences on the distribution, structure and heterogeneity of a population genetic heritage [20]. Preferential marriages limit freedom of choice, while retaining the heritage circulation within the clan [21]. From a sociologist viewpoint, individuals with similar characteristics have the tendency to wed together. This process of matrimonial choice is called homogamy [22]. It is known as endogamy when it is function of geographic locality. It could indeed depend on relationship, geographic isolation or social stratification [22-25]. Endogamy ascertains the power parents have on their kids, to a degree such as full participation in future spouse choice.

Most of the time, consanguinity weddings, i.e. with related subjects, are well-preferred within endogamous families. Such a practice is widespread in the Middle-East, North Africa and in South-West of Asia, representing higher than $50 \%$ of total marriages [26-30]. This matrimonial system seems well-maintained in the Arab world and in Maghreb countries [31].

A previous study in Algeria was performed in which a medical approach was used in order to seek unfavorable effects of consanguinity marriages on public health [32]. A more recent study described this type of union in urban and rural environments of Tlemcen area, considering the following criteria: structure (rate and type of relationship), social correlates, anthropological context and biological effects on the lineage [15]. Results showed that endogamy and consanguinity are more important in rural than in urban environment, where frequencies of marriages between related people represent $40.5 \%$ and $30.6 \%$ respectively. The importance of cultural context and educational level in spouse choice was particularly noticed in rural environment, with higher frequency than in urban environment of men with low educational level, especially in couples of related spouses.

Geneticists have classified consanguinity marriages according to consanguinity coefficient (f) $[26,33]$. High consanguinity levels result in losses of genetic variability, spoiled performances and increased risks of autosomal hereditary defect expression. In the present study, the clinical history of the studied patients families indicates a frequent consanguinity marriages notion among parents ( $\mathrm{f}=0.051$ and 0.016 respectively for Nedroma and Maghnia regions). Consanguinity thus appears as a promoting factor for LVM appearance. Our study agree well with previous results obtained by Bénallègue and Kedji [32] who correlated significant consanguinity levels to polymalformation risk in Algeria. By comparison of the Nedroma region known for its high endogamy level with the Maghnia region, where population is a lot less endogamous, one may clearly notice the higher pathology prevalence in Nedroma than in Maghnia (4 cases/38000 inhabitants vs 1 case/70000 inhabitants). Moreover, Risk of appearance of such pathology is 11 times higher in Nedroma than in Maghnia, regarding the studied families. Our results thus suggest that endogamy may well increase LVM prevalence. 
Table 2. Blood ABo System Type and Homozygous and Heterozygous A, B, O Alleles Frequency in Patients with Labial Venous Malformation and in their Parents

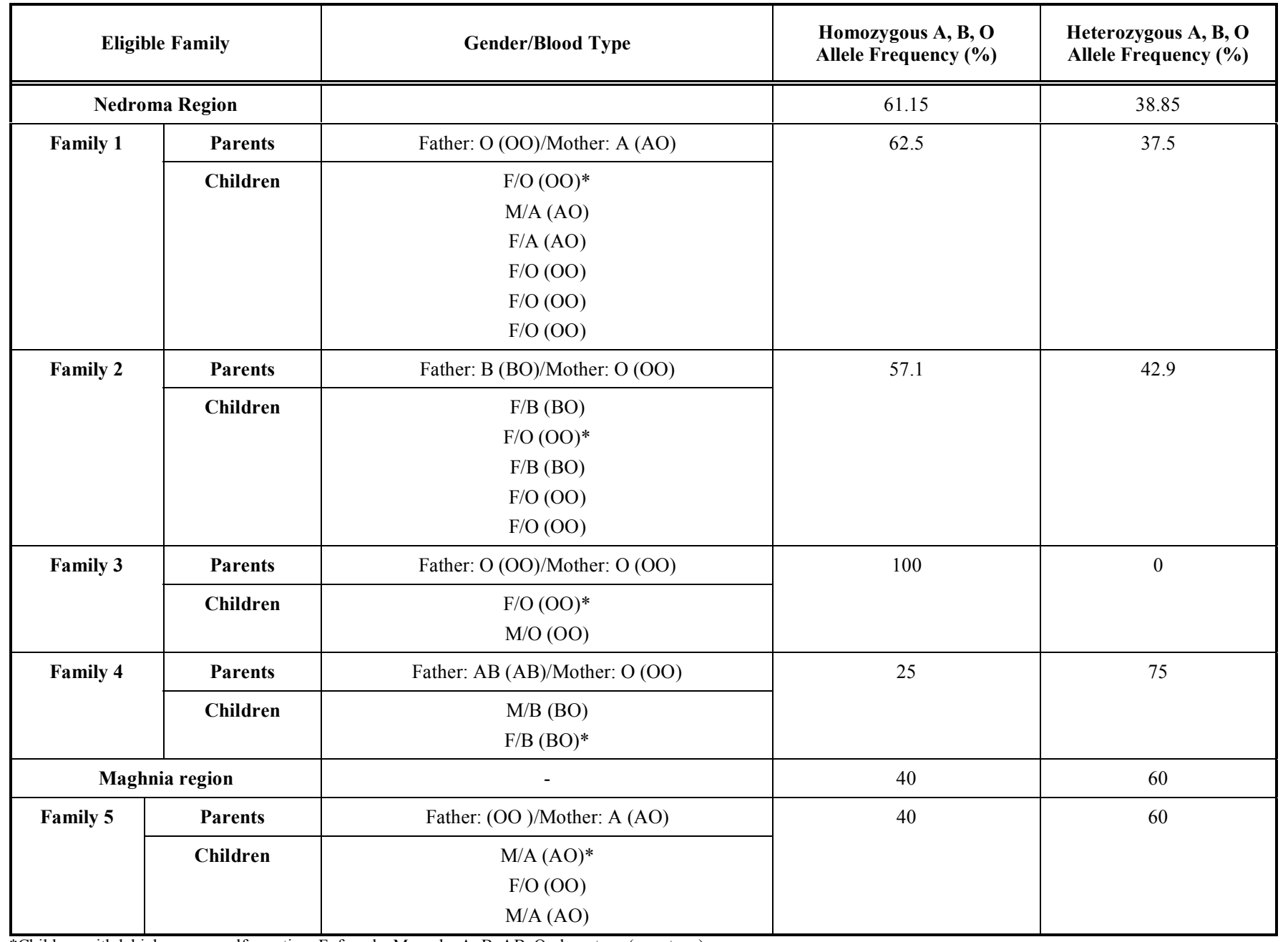

${ }^{*}$ Children with labial venous malformation. F: female. M: male. A, B, AB, O phenotype (genotype).

On the other hand, consequent to consanguinity is the increase of homozygote frequency and the decrease of the heterozygote one. The present study shows quite well the high homozygote alleles frequency, by comparison to that of heterozygote alleles in the Nedroma region, including patients with LVM $(61.15 \%$ vs $38.85 \%)$. Thus, these results attest well of consanguinity in the studied sample. Yet, homozygocity is lower than heterozygocity in the patient family from Maghnia (40\% vs 60\%). Thus, one can note that children of the studied families from the Nedroma region are higher in consanguinity than those from the Maghnia region.

Despite the high $\mathrm{O}$ alleles frequency in children with malformation by comparison with non-O alleles $(60 \%$ vs $40 \%$ ), it seems difficult to associate these alleles to LVM, considering the reduced number of the studied sample. Therefore, it would be interesting to identify SNP (single nucleotide polymorphism) alleles within chromosome $9 \mathrm{q}$, but also within chromosome $9 \mathrm{p}$ to confirm the implication of TIE-2 gene in the pathogenesis of these malformations in families of studied regions. Furthermore, previous studies done by Boon et al. [11] on three families generations with multiple venous, cutaneous and mucous malformations, suggested the implication of a $24 \mathrm{cM}$ locus on the short arm of chromosome $9(9 p)$ in the malformation development risk, knowing however that genes of the ABo system are all localized on the long arm of the chromosome 9 (9q) [34,35]. Nevertheless, if our study requires measuring the Odds ratio (OR), $\mathrm{O}$ allele association with LVM would not be excluded $(\mathrm{OR}=1.154)$. Such association remains nevertheless conjectural considering our non-representative sample, due to the extreme rarity of such pathology. Indeed, investigation showed a neat 1 case of vascular malformation per million inhabitants in the area of Paris, France (personal communication by Prof. Odile Enjolras, 2007).

\section{CONCLUSIONS}

In conclusion, a conducted study realized in two close geographic localities, yet far in levels of consanguinity/endogamy, lead to the conclusion that endogamy could increase LVM prevalence, and that consanguinity could beget its appearance. The postulated association between this pathology and the ABo system $\mathrm{O}$ alleles seems to be not confirmed.

Finally, functional labial disorders and especially esthetic prejudice of such malformations with facial localization as 
well as the resulting difficulties in social contacts result often times in school failure, particularly during the adolescence.

\section{ACKNOWLEDGEMENTS}

We would like to thank all families who generously participated in this study. We are also grateful to authorities of City Hall of Nedroma and Maghnia for agreement of this work, Doctor Latéfa Miraoui for assistance with data collection and Doctor Faïza Ghernaout for histological analysis. Special thanks are extended to Professor Gérard Lefranc for critical reading of the manuscript.

\section{CONFLICT OF INTEREST}

This work was partially supported by grants from the CNEPRU agency (Algeria).

\section{REFERENCES}

[1] Enjolras O, Mulliken JB. Vascular tumors and vascular malformations (new issues). Adv Dermatol 1997; 13: 375-423.

[2] Mulliken JB, Glowacki J. Hemangiomas and vascular malformations in infants and children. A classification based on endothelial characteristics. Plast Reconstr Surg 1982; 69: 412-20.

[3] Enjolras O, Wassef M. Classification et données physiopathologiques en matière d'"angiomes" superficiels. Sang Thrombose Vaisseaux 1998; 10: 563-71.

[4] El Kohen A, Benjelloun A, El Quessar A, et al. Superficial vascular anomalies of the face: apropos of six cases. Rev Stomatol Chir Maxillofac 2003; 104: 334-40.

[5] Stricker M, Picard L. Tumeurs vasculaires de la face: hémangiomes et malformations vasculaires. Encycl Med Chir. Elsevier, Paris; Stomatol 1998; 22-062-E-15: 23p.

[6] Lemarchand-Venencie F. Classification des angiomes: hémangiomes et malformations vasculaires superficielles. Rev Prat 1992; 42 : 1998-2004.

[7] Deffrennes D, Enjolras O, Salvan D, Herbreteau D. Traitement chirurgical des malformations vasculaires superficielles et des hémangiomes de la face. Encycl Med Chir. Techniques chirurgicales - Chirurgie plastique reconstructrice et esthétique 2001; 45146: $17 \mathrm{p}$.

[8] Enjolras O. Angiomes: hémangiomes et malformations vasculaires. Encycl Med Chir. Dermatologie 1996; 12-715-A10: 9p.

[9] Boon LM, Brouillard P, Irrthum A, et al. A gene for inherited cutaneous venous anomalies ("glomangiomas") localizes to chromosome 1p21-22. Am J Hum Genet 1999; 65: 125-33.

[10] Vikkula M, Boon LM, Carraway KL 3rd, et al. Vascular dysmorphogenesis caused by activating mutation in the receptor tyrosine kinase TIE 2. Cell 1996; 87: 1181-90.

[11] Boon LM, Mulliken JB, Vikkula M, et al. Assignment of a locus for dominantly inherited venous malformations to chromosome $9 \mathrm{p}$. Hum Mol Genet 1994; 3:1583-7.

[12] Brouillard P, Boon LM, Mulliken JB, et al. Mutations in a novel factor, glomulin, are responsible for glomuvenous malformations ("glomangiomas"). Am J Hum Genet 2002; 70: 866-74

[13] Casanova D, Boon LM, Vikkula M. Venous malformations: clinical characteristics and differential diagnosis. Ann Chir Plast Esthet 2006; 51:373-87.
[14] Aribi M, Moulessehoul S, Benabadji AB, Kendoucitani M. HLA DR phenotypic frequencies and genetic risk of Type 1 diabetes in west region of Algeria, Tlemcen. BMC Genet 2004; 5: 24.

[15] Zaoui S, Biemont C. Frequency of consanguineous unions in the Tlemcen area (West Algeria). Sante 2002; 12: 289-95.

[16] Zlotogora J, Hujerat Y, Barges S, Shalev SA, Chakravarti A. The fate of 12 recessive mutations in a single village. Ann Hum Genet 2007; 71: 202-8.

[17] Khan AO, Aldahmesh M, Meyer B. Recessive cornea plana in the Kingdom of Saudi Arabia. Ophthalmology 2006; 113: 1773-8.

[18] Bou-Assy F, Dumont S, Saillant F. Représentations sociales du mariage endogame et de ses conséquences biologiques sur la santé des descendants chez des fiancés apparentés. Cas de deux villages chiites au Liban. Serv Soc 2003; 50: 174-98.

[19] Geluda K, Bisaglia JB, Moreira V, Maldonado BM, Cunha AJ, Trajman A. Third-party informed consent in research with adolescents: the good, the bad and the ugly. Soc Sci Med 2005; 61: 985-8.

[20] Tremblay M, Heyer E, Saint-Hilaire M. Comparaisons intergénérationnelles de l'endogamie à partir des lieux de mariage et de résidence. L'exemple de la population du Saguenay. Cah Que Demogr 2000; 29: 119-146.

[21] Fargues $\mathrm{Ph}$. Traditions matrimoniales dans les sociétés arabes. Popul Soc 1986; 198: 4.

[22] Blackwell DL. Marital Homogamy in the United States: the influence of individual and paternal education. Soc Sci Res 1998; 27: 159-88.

[23] Danubio ME, Piro A, Tagarelli A. Endogamy and inbreeding since the 17th Century in past malarial communities in the province of Cosenza (Calabria, Southern Italy). Ann Hum Biol 1999; 26: 47388.

[24] Relethford JH, Mielke JH. Marital exogamy in the Aland Islands, Finland, 1750-1949. Ann Hum Biol 1994; 21: 13-21.

[25] Pettener D. Temporal trends in marital structure and isonymy in S. Paolo Albanese, Italy. Hum Biol 1990, 62: 837-51.

[26] Denic S. Consanguinity as risk factor for cervical carcinoma. Med Hypotheses 2003; 60: 321-4

[27] Bittles AH. Consanguinity and its relevance to clinical genetics. Clin Genet 2001; 60: 89-98.

[28] Hussain R, Bittles AH. The prevalence and demographic characteristics of consanguineous marriages in Pakistan. J Biosoc Sci 1998; 30: 261-75

[29] Nelson J, Smith M, Bittles AH. Consanguineous marriage and its clinical consequences in migrants to Australia. Clin Genet 1997; 52: 142-6.

[30] Bittles AH, Mason WM, Greene J, Rao NA. Reproductive behavior and health in consanguineous marriages. Science 1991; 252: 789 94.

[31] Chalbi N, Zakaria D. Modèles de famille, endogamie et consanguinité apparente en Tunisie. Essais de mesure. Popul Famille 1998; 1 : 39-59.

[32] Benallegue A, Kedji F. Consanguinité et santé publique. Une étude algérienne. Arch Fr Pediatr 1984; 41: 435-40.

[33] Denic S, Al-Gazali L. Breast cancer, consanguinity, and lethal tumor genes: simulation of BRCA1/2 prevalence over 40 generations. Int J Mol Med 2002; 10: 713-9.

[34] Tursen U, Tiftik EN, Unal S, et al. Relationship between ABO blood groups and skin cancers. Dermatol Online J 2005; 11: 44.

[35] Rockx BH, Vennema H, Hoebe CJ, Duizer E, Koopmans MP. Association of histo-blood group antigens and susceptibility to norovirus infections. J Infect Dis 2005; 191: 749-54.

This is an open access article licensed under the terms of the Creative Commons Attribution Non-Commercial License (http://creativecommons.org/licenses/by-nc/ $3.0 /$ ) which permits unrestricted, non-commercial use, distribution and reproduction in any medium, provided the work is properly cited 